\title{
The Asian Infrastructure Investment Bank: Bringing 'Asian Values' to Global Economic Governance?
}

\begin{abstract}
This paper examines the recent establishment of the Asian Infrastructure Investment Bank (AIIB) through the prism of the 'Asian values' debate. It maps the key attributes of these 'Asian values' first, to the established institutional governance structures of the AIIB, and second, to its proposed decision-making procedures; specifically, in relation to the criteria and process for evaluating, assessing, and monitoring the economic, social and environmental sustainability of infrastructure projects that this new Multilateral Development Bank (MDB) will be supporting. The object of this exercise is to postulate whether an 'Asian values' approach to international development finance can be proposed as a viable alternative to currently Western-dominated institutions of global economic governance and ultimately, the Anglo-American form of capitalism that still underpins the global economy. The twin roles of China within the AIIB, first as the financial catalyst for AIIB investment in regional infrastructure projects, and second, as a potential regional hegemon through its dominance of the AIIB governance structure, will be canvassed. The essay concludes by proposing an 'Asian values' approach to global economic governance as the foundation of a new research agenda which can be used to assess the future operations of this Bank and other new MDBs.
\end{abstract}




\section{Introduction}

The Asian Infrastructure Investment Bank (AIIB) is now formally inaugurated and 'open for business', with a remit to support the financing of infrastructure development in the Asia-Pacific region and beyond. Its status as the first multilateral development bank (MDB) for Asia established outside the Bretton Woods agreement that spawned the World Bank Group and the International Monetary Fund (IMF) is thus assured in history. The Asian, specifically Chinese, provenance of this new international actor in global economic relations raises many interesting issues for $21^{\text {st }}$ Century observers. This essay will address these issues through the prism of the 'Asian values' debate.

Following an initial discussion of the current standing of the 'Asian values' debate, the present study will map key attributes of a putative 'Asian values' approach to the aims, objectives, institutional governance structures and decision-making processes established by the newly-minted AIIB. The twin roles of China within the AIIB, first as the financial catalyst for AIIB investment in regional infrastructure projects, and second, as a potential regional hegemon through its dominance of the AIIB governance structure, will also be examined within this context.

This essay will then propose a research framework based on the 'Asian values' policy agenda for scrutinizing the upcoming work programme of the AIIB. In doing so, it is hoped that insights can be gained into whether an 'Asian values' approach to AIIB governance can achieve the elusive balance between the goals of sustainable economic growth, social resilience and environmental protection that are deemed fundamental to the future of humankind as a whole. The 
ultimate purpose of this research enterprise is to postulate whether the application of an 'Asian values' approach through the AIIB is a viable alternative to Western-dominated institutions for global economic governance, such as the World Bank Group and the IMF, as well as the specifically Anglo-American, form of capitalism that currently underpins the global economy.

\section{The ‘Asian Values' Approach in Global Governance Discourse}

The 'Asian values' approach, as well as the debate that this approach engendered, rose to prominence throughout the 1980 s and early 1990 s but then seemed to have lost its way during the (east) Asian financial crisis of the late 1990s. ${ }^{1}$ The original coining of the phrase: 'Asian values' is attributed variously to the founder and long-standing former premier of modern Singapore - the late Lee Kuan Yew, and the equally prominent former Malaysian prime minister, Mahathir Mohamad. ${ }^{2}$ However, it was the espousal of the 'Asian values' approach by the eminent Singaporean former diplomat and now academic dean, Kishore Mahbubani, 3 to explain a distinctive Asian way of

\footnotetext{
${ }^{1}$ For an overview of the impact of this regional financial crisis on the 'Asian values' debate, see Mark R Thompson, 'Whatever happened to "Asian Values"?', Journal of Democracy, Vol.12 (2001) 154-165.

${ }^{2}$ See: C. Y. (Chang Yau) Hoon, 'Revisiting the Asian Values Argument used by Asian Political Leaders and its Validity', Indonesian Quarterly, Vol.32, No.2 (2004) 154-174, at 154.

3 Currently, Dean and Professor in the Practice of Public Policy of the Lee Kuan Yew School of Public Policy at the National University of Singapore, having previously served for 33 years in Singapore's diplomatic service.
} 
government and the governance of business, 4 that arguably captured the zeitgeist of the Far East Asian 'Tiger' economies' 'miracle' in the late $20^{\text {th }}$ Century, as well as the astonishing growth of the Chinese 'Dragon' economy, going into the second decade of the $21^{\text {st }}$ Century. On the other hand, as Thompson notes, the 1997 East Asian economic crisis discredited the espousal of authoritarian 'Asian values' in Pacific Asia (East and Southeast Asia) as an overt explanation of the region's economic 'miracle'.5 Thus, ever since the initial articulations of an 'Asian values' approach to government and the institutional governance of business, a debate has ensued among policy-makers and commentators alike over the merits (or otherwise) of this approach. This essay will examine this much vaunted but also heavily criticised 'Asian values' approach in so far as it is applicable to the newly-minted Asian Infrastructure Investment Bank (AIIB).

A clear exposition of the 'Asian values' thesis would arguably provide a useful set of paradigm virtues against which to measure the model of economic governance as well as social and environmental standards adopted by AIIB. However, such an exercise may prove elusive. Acharya, for example, has commented on Asia's huge size and diversity, noting that there is not even a consensus over where its boundaries lie, and thus, no single conception, voice

\footnotetext{
4 A seminal event in this context is an interview with Mahbubani conducted by The Economist magazine (UK), entitled: 'Asian Values: Scourge of the West', reported on 22 April, 1995. Accessible at:

5 Mark R. Thompson , 'Pacific Asia after 'Asian Values': Authoritarianism, Democracy, and 'Good Governance", Third World Quarterly, Vol. 25, No. 6 (2004) 1079-1095 ， at 1079.
} 
or identity of Asia. ${ }^{6}$ As Dallmayr notes, when 'considered geographically, 'Asia' is a vast continent comprising a multitude of different cultural strands.' 7 However, the 'Asian values' approach is 'sometimes invoked in a starkly provocative manner, with the result that "Asian values" and human rights are pitted against each other as antithetical or incommensurable spheres.'8 In fact, as Emmerson has noted, '(t)he "Asian values” debate is not a formally organized oral disputation between two sides advancing contrary answers to the same question.'9

Mahbubani applied this arguably distinctive Asian take on the conduct of government and business through a series of hard-hitting speeches, op-ed columns, articles and other media outputs. ${ }^{10}$ He subsequently fleshed-out this initial foray with a detailed account of the 'Asian values' approach towards governance, international governance and latterly, international finance governance, in more recent contributions as well as books such as The New Asian Hemisphere: The Irresistible Shift of Global Power to the East (2008) ${ }^{11}$

\footnotetext{
${ }^{6}$ Amitav Acharya, 'Asia is not one', Journal of Asian Studies, Vol.69, No.4 (2010) 1001-1013. 7 Fred Dallmayr, “Asian values' and global human rights, Philosophy East and West, Vol. 52, No.2 (April, 2002 ) 173-189, at 178.

${ }^{8}$ Ibid.

9 Donald K. Emmerson, 'Singapore and the "Asian Values" Debate', Journal of Democracy, Vol.6, No.4 (October, 1995) 95-105, at ???

10 Many of these outputs can now be accessed from Mahbubani's personal website at: http://www.mahbubani.net/index.html

${ }^{11}$ Published by Public Affairs, Perseus Books Group, New York (2008).
} 
and The Great Convergence (2013) ${ }^{12}$. Mahbubani used arguments based on 'Asian values' as a riposte to what he saw as Western triumphalism in the post1990 era, in the wake of the end of the Cold War, rather than as an independent espousal of these so-called 'Asian values' themselves. The promotion of an 'Asian values' approach was formulated as an antithesis to perceived hegemonic Western notions of political and economic transcendence, especially in the aftermath of the fall of the Berlin Wall.

It is important to re-iterate that this Asian-oriented riposte against perceptions of Western transcendence has both political and economic dimensions. Mahbubani's politically-based criticism of the post-1990 Western viewpoint, especially when it rails against the notion of individual freedoms as an underpinning philosophical ideal of Western, and therefore all democraticallybased political systems, has been successfully rebutted by commentators, including those from within Asia itself. Responding to Lee Kuan Yew's meme for 'Asian values' in an interview with Fareed Zakaria for the Foreign Affairs journal, 13 for example, Kim Dae Jung observed that as an inevitable consequence of industrialization, family-centered East Asian societies are also rapidly moving toward self-centered individualism. ${ }^{14}$ Moreover, what Lee and his supporters see as social and individual moral breakdown is attributable not

\footnotetext{
${ }^{12}$ Full title: The Great Convergence: Asia, the West, and the Logic of One World, Public Affairs (2013)

${ }^{13}$ Fareed Zakaria, 'Culture is Destiny - A Conversation with Lee Kuan Yew', Foreign Affairs Vol.73, No.2 (March/April 1994) 109-126.

${ }^{14}$ Kim Dae Jung, 'Is Culture Destiny? The Myth of Asia's Anti-Democratic Values', in Response section, Foreign Affairs, Vol.73, No.6 (November/December, 1994)
} 
to inherent shortcomings of Western cultures per se but to those of industrial societies in general; with Kim noting that a similar phenomenon is now spreading through Asia's newly industrializing societies. ${ }^{15}$ More generally, reliance on 'Asian values' has not necessarily translated to new or different paradigms for global governance. As Acharya has observed, 'the leading Asian powers-China, India and Japan-while seeking global leadership, seem to be more concerned with developing and legitimizing their national power aspirations (using the traditional notions and means of international relations) than with contributing to global governance.'16

Mahbubani and his fellow ‘Asian values' promoters have achieved more success on the economic front. To begin with, he argues that Asian economies have derived their success from the adoption of certain attributes of Western capitalism, notably, a commitment to open markets and the rule of law. However, he then outlined three challenges facing the Western, and specifically Anglo-American, varieties of capitalism. First, the political subservience of successive Western and especially Anglo-American governments to capitalism as an ideological good rather than a pragmatic instrument through which to improve human welfare. Second, the continuing need for good governance, including regulatory and supervisory institutions to ensure capitalism works well. Third, the need to ensure equality of work opportunities, while providing

\footnotetext{
15 Ibid.

${ }^{16}$ Amitav Acharya, 'Can Asia lead? Power ambitions and global governance in the twenty-first century', International Affairs, Vol.87, No.4 (2011) 851-869, at 851.
} 
a measure of social protection from the white-heat of competition in global markets for goods and services.

Acknowledging that for all its flaws, capitalism remains the best way to improve human welfare, Mahbubani has nevertheless argued that Asian countries have begun to address all the above existential challenges to capitalism itself better than their Western counterparts. For example, when Asian governments promoted investment and jobs creation to stave of unemployment, Western capitalists derided these policy interventions as market interference but when unemployment rose in the Western economies, this was allegedly due to unfair competition of cheap goods and labour from East Asia. ${ }^{17}$

There is thus a continuing debate over the existence, evidence for, and intrinsic value of the 'Asian' approach within the specific context of governance of the global political economy. Underpinning the Mahbubani thesis is a new, Asianoriented, assertiveness in world affairs and international relations. This Asian resurgence is in line with growing regional economic prosperity and political stability. Moreover, it is no longer limited solely to the well-known Far East Asian 'Tiger' and Chinese 'Dragon' economies but now much more geographically wide-spread, especially throughout mainland and archipelagic East Asia, as well as South Asia. This new Asian assertiveness can also be abrasive, especially when it comes to alleged instances of double-standards. For example, the very strictly imposed IMF conditional bailouts of East Asian

\footnotetext{
${ }^{17}$ Kishore Mahbubani, 'Western capitalism has much to learn from Asia', Financial Times newspaper (UK) 7 February, 2012.
} 
economies in the late 1990s, which allowed several major domestic banks to go the wall, is contrasted with the relative ease with which a similar IMF bailout was offered to Greece during the financial crisis of 2008-2009. ${ }^{18}$ This was in addition to generous Western national government protection of large AngloAmerican and European-based banks at the same time. As Rachman notes, '( $t$ )he perception of bias towards the West is even more problematic when it comes to the world's two leading international economic institutions - the IMF and the World Bank.'19

Distilling the essence of all these contributions to the 'Asian values' debate, it is possible to enumerate these 'Asian values' themselves, alongside further iterations of their implications only in general terms, as follows: First, at its heart, the 'Asian values' approach is a claim to the positive aspects of 'groupthink'20, rather than (Western) individualistic, freedom-based method of setting and achieving collective goals for business and/or government. Buruma, for example, re-iterates Lee Kuan Yew's argument was that Asians were used to putting the collective good above individual interests. They are communitarian

\footnotetext{
${ }^{18}$ Gideon Rachman, Easternisation: War and Peace in the Asian Century, London: Bodley Head (2016) at 230.

${ }^{19}$ Ibid., at 229.

${ }^{20}$ The use of 'groupthink' in this context is a reference to its original meaning as used by William H. Whyte, Jr., who coined the term in 1952 in Fortune magazine: 'Groupthink being a coinage - and, admittedly, a loaded one - a working definition is in order. We are not talking about mere instinctive conformity - it is, after all, a perennial failing of mankind. What we are talking about is a rationalized conformity - an open, articulate philosophy which holds that group values are not only expedient but right and good as well.'
} 
rather than individualistic in their orientation, and naturally obedient to higher authority. These traits were rooted in Asian history: they were deep 'Asian values'. ${ }^{21}$

Lee himself later re-cast these values as specifically Confucian (Chinese) ideals of individual, family and State relationships, ${ }^{22}$ thus 'muddying the waters' somewhat as to the true provenance of so-called 'Asian values'. As Dallmayr observes, "the term "Asian values" has been linked chiefly with Confucian teachings, with Buddhist and Taoist legacies being treated more like variations on, or internal reactions to, the former; still, to avoid oversimplification, some awareness of diversity should be maintained.' 23 According to Donnelly, this Asian/Chinese system of values and social relations is incompatible with the vision of equal and autonomous individuals that underlies international human rights norms'.24

${ }^{21}$ Ian Buruma, Asian Values RIP, Project Syndicate, posted: 4 April, 2015. Accessible at: https://www.project-syndicate.org/commentary/asian-values-lee-kuan-yew-by-ian-buruma2015-04

${ }^{22}$ See: Lee Kuan Yew \& Terry McCarthy, "In Defense of 'Asian Values"', Time magazine, Vol.151, No.10 (16 March, 1998) \& Michael Barr, "Lee Kuan Yew and the 'Asian Values' Debate", Asian Studies Review Vol.24, no.3 (September, 2000) 313.

${ }^{23}$ Dallmayr (2002) op. cit., at 178.

${ }^{24}$ Jack Donnelly, 'Human Rights and Asian Values: A Defense of 'Western' Universalism', in Joanne R. Bauer and Daniel A. Bell, eds., The East Asian Challenge for Human Rights (Cambridge: Cambridge University Press, 1999) at 80. 
Second, as the 'Asian values' approach is also structured around duties not rights, 25 it is characterised by a prioritised individual commitment to predetermined group or community goals. At the level of government, this is manifested by patient, consensus-based and deliberative decision-making processes on important or significant issues of the day. These collective decisions aim to achieve community goals, rather than individual preferences or targets. On the other hand, once such group-based collective decisions are made, swift progress to implement such decisions can be made, with a 'can-do' attitude prevailing. This is at least in part due to the absence of any individual loose cannons whose views were presumably already dealt with during the consensual decision-making process undertaken prior to the collective decision. This avowed Asian value of subsuming individual preferences to the collective group interest may prove to be a welcome difference to Westernbased international institutions dominated by strong individual personalities, whose external high profiles often belie internal institutional discord and insufficiently detailed attention to the work at hand.

Finally, any disputes that remain or arise in an Asian regional context are usually resolved, or at least managed, in a consultative and consensus-based manner, with an emphasis on ensuring no individual 'loss of face'. Irreconcilable differences are not allowed to fester in the foreground, but instead politely set aside or firmly placed in the background, at least until an

\footnotetext{
25 Yash Ghai, 'Rights, Duties and Responsibilities', in Josiane Cauquelin, Paul Lim and Birgit Mayer-Konig, eds., Asian blues: Encounter with Diversity (Surrey: Curwn, 1998) 29.
} 
opportune future moment arises for their resolution, possibly in conjunction with the settlement of several other issues between the parties, so that one party's compromise over a single issue is matched by the opposing party's reconciliation on another pressing topic. Thus, it is no surprise that many Asian countries still prefer to settle their international disputes through the more traditional and longer-standing mode of diplomatic negotiations.

There is also an emphasis on the promotion of long-term, 'win-win' solutions across a broad spectrum of bilateral interests that exist between the two parties, rather than focussing on short-term, legal 'victories' on specific issues of disagreement between them. In this sense, the 'Asian values' approach to dispute settlement eschews winner-take-all confrontations, particularly the publicized manifestations thereof, in the form of international litigation that clearly distinguishes between winning and losing parties. Instead, the 'Asian values' approach is in favour of negotiated, albeit highly compromised, solutions. Understanding this emphasis on long-term solutions rather than short-term gain would, for example, explain the muted reactions of fellow Association of South-East Asian Nations (ASEAN) members to the recent international arbitral tribunal award that is ostensibly in favour of the Philippines in its ongoing dispute with China over certain maritime features in the South China Sea. ${ }^{26}$

\footnotetext{
${ }^{26}$ This tribunal was established under Annex VII of the UN Convention on the Law of the Sea Convention (UNCLOS) and convened under the auspices of the Permanent Court of Arbitration (PCA). See: South China Sea Arbitration Award, Philippines v China, 12 July, 2016, PCA Case No.2013-19. Available at:
} 
While the more idealized aspects of this summarized set of elements of the ‘Asian values' approach will be questioned by many observers and criticized by others, there can be little doubt that Mahbubani and his fellow travellers have tapped into a powerful alternative narrative for explaining the tremendous socio-economic successes of Far Eastern polities in Asia, initially in relation to the 'Tiger' economies of Singapore, Taiwan and South Korea, and latterly, with the rapid emergence of the Chinese 'Dragon' economy. In particular, it is important to note that the 'Asian values' approach emphasizes the need for continuing social cohesion of national communities in Asia, even in the face of increasing material wealth. This is a significant differential indicator from Western-style materialism, which due to its perceived individualism is seen as leading inexorably to social inequality and thence to social division. This is despite increasing evidence of social breakdown due to materialistic

However, this emphasis on social cohesion above all else often results in tolerance for authoritarian, rather than laissez-faire, forms of democratic government. Democracy itself is not disputed as a global public good, simply the form of capitalist-based democracy that favours rampant individualism at the expense of others. The much-touted evidence for this continuing sense of community within Asian societies usually relies on the relatively low level incidence of domestic crime, and the much less litigious nature of business and personal relationship breakdowns. To be sure, several of these measures are now exhibiting ambivalent trends but the over-riding feeling remains one in

https://pca-cpa.org/wp-content/uploads/sites/175/2016/o7/PH-CN-20160712-Award.pdf 
which these 'Asian values' do amount to something tangibly different in the socio-economic make-up of many modern Asian societies, especially in the eastern and southern Asian regions.

The net effect of this different approach to the relationship between governmental forms and socio-economic progress is that Asian views on governance in general, and economic governance in particular, have begun to diverge from mainstream Anglo-American thinking. Unlike the AngloAmerican reticence on government regulatory controls of the markets, Asian polities have traditionally not looked at government itself as the problem. ${ }^{27}$ Indeed, most Asian policy-makers habitually work on the pragmatic assumption that in the real world, it is the balance between the 'invisible hand' of free markets and the 'visible hand' of good governance that is all-important in a nation's pathway to social cohesion and economic prosperity. ${ }^{28}$ According to Chesterman and Mahbubani, good governance is not only about 'inputs' such as the legitimacy and representative aspects of government but more about its so-called 'outputs': Is government realizing its socio-economic goals effectively, efficiently and equitably?29 This is despite the obvious rejoinder as to whether those who decide these goals and how they are to be achieved in an Asian

\footnotetext{
${ }^{27}$ Kishore Mahbubani, 'Commentary: New Asian Perspectives on Governance', in Governance: An International Journal of Policy, Administration and Institutions, Vol.23, No.2 (April, 2010) 205-208, at 205 .

${ }^{28}$ Ibid., at 207.

${ }^{29}$ Simon Chesterman and Kishore Mahbubani, ‘Can Asians Resolve Global Problems?' Project Syndicate (2010) Accessible at http://www.project-syndicate.org
} 
context are in themselves democratic and transparent in their decision-making processes.

The apparently realist perspective engendered by the 'Asian values' approach would seem to have resulted in a non-generic attitude to the construction of institutional governance forms, emphasizing the need to find out what works in any given situation, rather than establishing institutional structures based on an ultimately misplaced ideological commitment to purity of substance and form. Indeed, as Mahbubani and Summers suggest, the Asian experience shows that "modernization does not simply equal westernization - that it is possible to pursue, say, economic and social development while still retaining distinctive cultural characteristics.' 30 However, many fear this trend may lead to revisionist foreign policies that seek to end not just regional hegemonic dominance by the United States, but eventually also the global institutions created by the United States and Europe over the last 70 years. ${ }^{31}$

On the other hand, as Acharya has noted, '(A) central challenge facing global order today is the seeming contradiction between the desire of Asia's leading states to be recognized and treated as global powers on the one hand, and their limited and hesitant contribution to global governance on the other.'32 Mathews

\footnotetext{
3о Kishore Mahbubani and Lawrence H., 'The Fusion of Civilizations: The Case for Global Optimism', Foreign Affairs, Vol.95 No.3 (May/June, 2016) 126-135, at 129.

${ }^{31}$ John Mearsheimer, 'The gathering storm: China's challenge to US power in Asia', Chinese Journal of International Politics, Vol.3,No.4 (2010) 381-96. ${ }^{32}$ Acharya, International Affairs (2011) op. cit., at 852.
} 
agrees, pointing out that Asian countries have so far been beneficiaries, rather than creators of international regimes and institutions conceived and built by the West, inter alia, to manage global finance and underwrite economic development.33 This view is echoed by Feigenbaum, specifically in relation to China, when he notes that 'China is a disruptive power but not a revolutionary one. Its size, wealth, and assertive foreign policy lead it to demand significant changes to existing institutions, but it does not seek to overturn the current international order wholesale.'34 While no overtly global alternatives have so far been proposed by Asian economies in the international finance sector, the emergence of regional finance institutions with far-reaching aspirations, such as the Chinese-sponsored Asian Infrastructure Investment Bank (AIIB), has led to speculation on the sustainability of existing global finance institutions such as the World Bank and the IMF.

Chinese dominance of this new international finance institution has also spawned criticism of its own perceived hegemonic tendencies. In countering both the conceptual assumptions of the prevailing world economic order as inherently liberal and democratic, as well as promoting the Chinese role within this new economic governance model, Zhang offers two valuable insights from existing literature: 'One is that China is rising within an order not of its own

\footnotetext{
33 Jessica T. Mathews, 'Can China Replace the West?' a review article of Rachman's 'Easternization' (sic) (2016) op. cit., in The New York Review of Books (NYRB), Vol.LXIV, No.8, May 11-24, 2017, 14-16, at 16.

34 Evan A. Feigenbaum, 'China and the World: Dealing With a Reluctant Power', Foreign Affairs (January/February, 2017) 33-40, at 33.
} 
making. The People's Republic of China (PRC) was not "present at the creation" of the key global economic institutions such as the IMF and the World Bank. Until very recently, it has always been a rule/norm taker rather than a rule/norm maker in the expanding institutional networks for global governance. ... The second point is (the) historically unusual pattern of concentration of power is not seen only in the unprecedented preponderance of American power in both material and ideational terms. It is also reflected in the arrival of China, a non-western power with a self-proclaimed developing country identity and an authoritarian regime, as the second among equals in the Great Power club, arguably with its own purpose and project.'35

On the other hand, Oliver and Williams have noted that the United States has countered this perception of emerging Asian initiatives through efforts such as the Trans-Pacific Partnership (TPP) and proposed Transatlantic Trade and Investment Partnership (TTIP), both of which are intended to boost the existing rules-based system. ${ }^{6}$ President Trump's pre-emptive withdrawal from the TPP, when coupled with his stated desire to do the same with the still-to-be negotiated TTIP, arguably acts to strengthen China's role within this Great Power club, especially within the economic sphere.

\footnotetext{
35 Yongjin Zhang, 'China and liberal hierarchies in global international society: power and negotiation for normative change', International Affairs, Vol.92, No.4 (2016) 795-816, at 797. ${ }^{36}$ Tim Oliver and Michael John Williams, 'Special relationships in flux: Brexit and the future of the US-EU and US-UK relationships', International Affairs Vol.92, No.3 (2016) 547-567, at 551, citing Ramesh Thakur, 'A lesson in the geopolitics of infrastructure finance', Japan Times, 21 June 2015 .
} 
A further and intriguing Great Powers-related perspective to bring to bear in the overall global geo-political situation is the notion that China itself may be looking over its shoulder at the emerging role of India as a competing future global economic power on the Chinese south-western flank. As Mahbubani and Summers have observed, '(a)lthough China's rise has been one of the universally acknowledged wonders of the age, India's recent rise has been impressive as well, as India, too, has embraced modernization, globalization, and Enlightenment rationalism. Along the way, India has maintained the world's largest democracy, successfully accommodated an amazingly diverse cultural and demographic mosaic, ...'37

In this regard, India has already voiced concerns over its place within the geographical framework of the Chinese Economic Belt and Maritime Silk Road initiative, fearing that these major infrastructure links 'will create a Chinese sphere of influence that will encircle India.' 38 As Cai has recently pointed out, there is a significant lack of political trust between China and a number of important regional countries along the 'Belt and Road' routes. India, for example, has stated that it would not commit to buy-into this unilateral Chinese initiative without significant consultation. 39 Rachman concludes that 'these

\footnotetext{
37 Mahbubani \& Summers (2016) op. cit., at 133.

${ }^{38}$ Gideon Rachman, 'China, India and the clash of two great civilizations', Financial Times, UK newspaper, 6 June, 2017, at 13.

39 Peter Cai, Analysis: Understanding the Chinese Belt \& Road Inititative, Lowy Institute for International Policy, Sydney, Australia (March, 2017) 22pp, at 15. Accessible at: https://www.lowyinstitute.org/sites/default/files/documents/Understanding\%20China's\%20 Belt\%20and\%20Road\%20Initiative WEB 1.pdf
} 
arguments reflect the fact that China and India represent more than just rival powers but rival political systems, ideologies, even civilizations' 40 , such that 'it is the contest between China and India that may ultimately shape the $21^{\text {st }}$ Century.'41

\section{'Asian Values' and Global Economic Governance}

Given the divergence between Asian and Western attitudes to governance in general, and financial system governance in particular, as exemplified by the 'Asian values' approach, it is worth asking what contribution (if any) this approach can bring to the new economic governance forms that are beginning to take shape in this region such as the AIIB and the TPP. This question is pertinent bearing in mind that the former institution (AIIB) is currently proceeding without US participation, albeit with less antagonism than previously expressed, $4^{2}$ whereas the latter agreement (TPP) was initially adopted between the US and several of its Asian allies without Chinese input, but may now be turning towards accepting a role for China for its salvation, following the US withdrawal.

As David Dollar of the Brookings Institution has observed, with China pursuing the AIIB and other initiatives that currently do not include the USA, while the TPP did not involve China, this creates a risk of competing blocs and

\footnotetext{
40 Rachman, Financial Times (2017) op. cit., at 13.

${ }^{41}$ Ibid.

${ }^{42}$ Shawn Donnan, 'White House declares truce with China over AIIB', Financial Times, 27 Sept. 2015. Accessible at: https://www.ft.com/content/23c51438-64ca-11e5-a28b-50226830d644
} 
institutions. Here, Dollar's perceptive insight on the potentially mutual benefit of both these broad regional initiatives paves the way for reconciliation between them. Using the metaphors of 'hardware' and 'software' for international economic integration, wherein AIIB financial support for significant infrastructure is the necessary 'hardware' of economic integration, while the TPP (or its successor) is the 'software', Dollar argues that by bringing this 'hardware' and 'software' together, the outcome could be a more integrated Asia Pacific economy.43 Optimistically, he concludes that the AIIB is likely to become a part of the global financial architecture in such a way as to make the other MDBs more effective.

Moreover, he predicted that China and other Asian countries that are presently not involved in TPP (or its successor) are likely to join this arrangement if it is successful so that the most likely outcome is that the world ends up with a more robust and inclusive set of global economic institutions. 44 Dollar's prediction of eventual Chinese engagement with the TPP has therefore proved prescient, albeit for a very different reason than he projected. Following the US withdrawal, it is notable that TPP parties are pivoting towards China to salvage this Agreement. Mathews observes that 'China sent high-level officials to a meeting of the eleven remaining TPP members to discuss forming a new

\footnotetext{
43 See David Dollar, 'Lessons for the AIIB From the Experience of the World Bank', in China on the Global Stage: Yuan Internalization, the SDR basket, and the Asian Infrastructure Investment Bank, Bloomberg Brief (27 April, 2015) 13pp., at 8. Accessible at: $\underline{\text { www.bloombergbriefs.com }}$

44 Ibid.
} 
regional trade regime in which it (China), and not the US, would be a member.'45

As Madhur notes, the perceived need for Asia to play a major role in setting the agenda for global economic governance and designing the institutional architecture for achieving this agenda reflects the fact that the centre of gravity of the global economy has shifted towards Asia, with this trend being likely to continue in the decades to come. Asia's growing economic weight enhances its potential to play a much stronger role in shaping $21^{\text {st }}$ century global economic governance. ${ }^{46}$ However, he cautions that realization of that potential will depend upon how successfully Asia addresses five key challenges: rebalancing sources of economic growth; strengthening national governance; institutionalizing regional integration; providing political leadership; and adopting the global lingua franca - English. While the 'Asian values' debate arguably presaged the growing ambition of Asian policy-makers on global economic governance matters, Madhur questions whether their appetite for addressing the necessary policy challenges is keeping pace with that ambition. He concludes that the continuing gap between ambition and action will need to be closed before Asia can play a larger role in global economic governance. 47 This echoes a cautionary note at the end of Ikenberry's review of The New Asian

\footnotetext{
45 Mathews, NYRB review article (2017) op. cit., at 16.

46 Srinivasa Madhur, 'Asia's role in twenty-first-century global economic governance', International Affairs, Vol.88, Issue 4 ( July, 2012) 817-833, at 817.

47 Ibid.
} 
Hemisphere, ${ }^{48}$ where he acknowledges that although Mahbubani makes a compelling case for a Western strategy of power sharing with Asia, he is less convincing in arguing that Asia will be more competent and enlightened in its stewardship of the world.

So, what can the 'Asian values' approach bring to the global governance table? Here, Chesterman and Mahbubani have outlined both the positive and negative elements of a putative Asian approach to the challenges of global governance, as follows: 'The positive aspects include respect for diversity and an emphasis on consensus-building over conflict, practical solutions over lofty principles and gradualism over abrupt change. On the other hand, the desire to avoid confrontation can prevent meaningful agreements from being reached in a reasonable timeframe, and the appearance of consensus may merely mask the true politics at work.' 49 Thus, implementing the positive aspects of an 'Asian values' approach may result in more inclusive decision-making in global governance institutions, but also invites the possibility of stalemate, or more rhetoric than substance. $5^{\circ}$

\footnotetext{
${ }^{48}$ John Ikenberry, Capsule (Book) Review of 'The New Asian Hemisphere: The Irresistable Shift of Global Power to the East', in Foreign Affairs (March/April, 2008)

49 Chesterman and Mahbubani, 'Can Asians Resolve Global Problems?' (2010) op. cit. See also: Mahbubani and Chesterman, Asia's Role in Global Governance: World Economic Forum Global Redesign Initiative - Singapore Hearing, Lee Kuan Yew University School of Public Policy Public Policy Research Paper No. LKYSPP1O-002, as well as New York University School of Law, Public Law \& Legal Theory Research Paper Series No. 10-09 (2010)

${ }^{50}$ Chesterman and Mahbubani, 'Can Asians Resolve Global Problems?' (2010) ibid.
} 
Despite these concerns, Mahbubani has continued to be stark in his assessment of the potential of the AIIB when juxtaposed against the currently Westerndominated public international development finance institutions. He baldly observes that the World Bank, IMF and their related bodies have become overbureaucratic and sclerotic, while expressing the hope that China would be able to develop a lean and mean bureaucratic machine to run the AIIB. ${ }^{51}$ Indeed, Mahbubani is looking forward to the Chinese doing a better job of managing this new institution, and thus introducing new rules in the international finance game that the majority of the countries around the world may find more congenial. $5^{2}$

By contrast, Elek has struck a more conciliatory and arguably also more realistic note by observing that the AIIB is meant to supplement, not supersede let alone replace, the World Bank and its regional sister institutions such as the Asian Development Bank, African Development Bank, European Bank for Reconstruction and Development (EBRD), and Inter-American Development Bank. He also notes presciently that drawing from the expertise of experienced MDBs would be the most efficient way to build the capacity of the new bank to assess and implement a rapidly growing number of projects successfully. Widespread participation by governments who are also significant shareholders in the World Bank and the Asian Development Bank would

\footnotetext{
${ }^{51}$ Mahbubani, 'World needs new hands on the global finance tiller', East Asia Forum, Posted on: 23 June, 2015. 4pp, at 2-3. Accessible at: http://www.eastasiaforum.org ${ }^{2}$ Ibid.
} 
maximize the potential for synergy.53

This need for re-conciliation between Asian and Western perspectives is imperative given the initial concerns expressed by the (US) White House National Security Council over whether the AIIB will meet the high standards of the World Bank, particularly related to governance, and environmental and social safeguards. 54 Luft is critical of what he sees as a misguided approach of the United States to the AIIB in this regard, which he suggests has been futile. 55 Moreover, he notes that it risks allowing China to shape Eurasia's economic and political future without U.S. input, denies American investors opportunities to profit from major infrastructure projects; and could stifle a source of muchneeded growth for Asia's developing economies and Europe’s stagnating ones. 56

Possibly in response to U.S. skepticism over the AIIB's role as a new MDB in the world of international development finance, the AIIB has recently stated that: 'AIIB will work in close cooperation with other international financial institutions and international organizations concerned with economic

\footnotetext{
53 Andrew Elek ‘Welcoming China’s Asian Infrastructure Investment Bank initiative’, East Asia Forum, posted on 21st September, 2014, 3pp., at 2. Accessible at: http://www.eastasiaforum.org

54 See: 'UK to join China-backed Asian development bank', on Reuters website, 13 March, 2015. Accessible at:

http://in.reuters.com/article/britain-asia-bank-idINKBNoM9o6C20150313

55 Gal Luft, 'China's Infrastructure Play: Why Washington Should Accept the New Silk Road', Foreign Affairs, Vol.95, No.5 (September/October, 2016) 68-75, at 71-72.

${ }^{6}$ Ibid.
} 
development of the region or the Bank's operational areas. Its activities will complement and supplement the programs of both the existing and newly established MDBs, such as the New Development Bank (NDB) formed by the BRICS States. 57 The existing MDBs have been generous in sharing their expertise and lessons of their experiences with AIIB. The Secretariat is actively exploring potential for co-financing with other MDBs once AIIB becomes operational.' 58

Notwithstanding these AIIB overtures to other MDBs, the fact remains that to sustain their continuing socio-economic growth, Asian infrastructure development finance is imperative. For example, the Asian Development Bank Institute (ADBI), estimates that developing Asian economies will need to invest US $\$ 8$ trillion from 2010 to 2020 , just to keep pace with expected infrastructure needs, with more than $32 \%$ of this projected figure needed just to maintain or replace current infrastructure.59 Luft observes that '(o)ver the course of the next

57 BRICS is the acronym for an association of five major emerging national economies: Brazil, Russia, India, China and South Africa. The Agreement on the New Development Bank (NDB) including its Articles of Agreement, was adopted during the sixth BRICS Summit in Fortaleza, Brazil on July 15, 2014. Accessible at: https://www.ndbbrics.org/agreement.html

${ }^{8}$ See: 'Cooperation with existing and new Multilateral Development Banks (MDBs)', in ‘Additional Information' on AIIB website, available at :

http://euweb.aiib.org/html/pagefaq/Additional/

59 Asian Development Bank, Infrastructure for supporting inclusive growth and poverty reduction in Asia, Mandaluyong City, Philippines: Asian Development Bank (2012) 87pp, at 14. Accessible at: https://www.adb.org/sites/default/files/publication/29823/infrastructuresupporting-inclusive-growth.pdf

See also: Biswa Nath Bhattacharyay, Infrastructure Development for ASEAN Economic 
four years, Asian countries will need around US $\$ 800$ billion annually to build the transport, energy, and communications networks that they require to achieve their development goals.'6o

At the same time, the 2008 global financial crisis has reduced the overall capital lending sums of the World Bank Group, ${ }^{61}$ including the Asian Development Bank (ADB). Thus, the investment provided by these MDBs meets less than ten percent of this overall need so that even if the AIIB and China's other funding outfits live up to their promise, the money will still fall short. ${ }^{62}$ Moreover, private international finance for infrastructure has also fallen to one-third of its pre-crisis total. 63 Hence, the enthusiastic welcome for the AIIB among Asian developing economies. Mahbubani, for example, is in no doubt that the AIIB and to a lesser extent, the New Development Bank (NDB), ${ }^{64}$ can emerge as competing international finance development institutions to the traditionally

Integration, ADBI Working Paper No. 138 (May, 2009) Accessible at: http://www.adb.org/sites/default/files/publication/155993/adbi-wp138.pdf

${ }^{60}$ Luft (2016) op. cit., at 72.

${ }^{61}$ Keshav Kelkar, 'BRICS, banking on development', East Asia Forum, 11 September 2014. Accessible at: http://www.eastasiaforum.org/2014/o9/11/brics-banking-on-development/

${ }^{62}$ Luft (2016) op. cit., at 72.

${ }^{63}$ Kelkar (2014) op. cit.

64 The NDB is headquartered in Shanghai, China, with an initial authorized capital of US\$100 billion and a mandate to strengthen cooperation among BRICS economies and supplement the efforts of multilateral and regional financial institutions for global development, thus contributing to collective commitments for achieving the goal of strong, sustainable and balanced growth. Information on the NDB is available at: http://www.ndb.int 
Western-dominated World Bank Group and IMF. 65

In its 2015 Global Economic Situation and Prospects report, the UN noted with approval such regional financing initiatives as the NDB and the AIIB for creating the 'potential for scaling up financing' 66 as well as 'provide additional resources for investment in sustainable development.' ${ }^{67}$ The new AIIB has an authorized capital base of US $\$ 100$ billion, with $\$ 10$ billion as initial paid-in capital. China is expected to provide half of the capital. Moreover, as the UN report observed, given that China has the highest credit rating among the BRICS countries, its outsized capital contribution to the AIIB may result in an even better than expected credit rating for the AIIB, and thus enable it to borrow on better terms than the NDB. This could potentially enable AIIB to disburse higher volumes and values of loans compared to the NDB, particularly for infrastructure investment. 68

On the other hand, since China has contributed to the capitalization of the AIIB from its own reserves, the well-known phrase: 'he who pays the piper, calls the tune' comes to mind. The difficult task therefore will be to safeguard the AIIB from simply becoming a vehicle for furthering Chinese national interests. In

\footnotetext{
65 Mahbubani, 'Sailing on the Same Boat', Speech at Third International Conference on Financing Development, on 8 June, 2015. Available at: http://www.un.org/esa/ffd/ffd3/blog/sailing-on-the-same-boat.html ${ }^{66}$ World Economic Situation and Prospects 2015, New York: UN (2015) at 73. Available at: http://www.un.org/en/development/desa/policy/wesp/wesp_archive/2015wesp_full_en.pdf ${ }^{67}$ Ibid., at 75 . 68 Ibid., at 75 .
} 
response to concerns over the perceived dominance of China within the AIIB, Dollar points out: 'Now that a diverse group of nearly 60 countries have signed up, it would be difficult for China to use the bank to finance projects in favoured countries over the exclusion of other members.' 69 This is pertinent, given both the geographically widespread and geo-politically significant membership of the AIIB, including major European powers such as Germany, France, and the UK, as well as India and Australia, among its Founding Members.70

Nevertheless, the over-arching Chinese strategic vision for the AIIB clearly envisages its prominent role in the Chinese One Belt, One Road (OBOR), also known as the 21st-Century Maritime Silk Road and Economic Belt initiative. ${ }^{71}$ Through this initiative, China hopes to 'build a community of shared interests, destiny and responsibility featuring mutual political trust, economic integration and cultural inclusiveness.' 72 Specifically, the Economic Belt initiative will mainly be composed of transport infrastructure projects aimed at creating an 'economic belt' linking China with Mongolia, central Asia, Russia,

${ }^{69}$ David Dollar, 'What the AIIB can learn from World Bank shortcomings', Bloomberg Brief (2015) op. cit.

70 The AIIB Membership list available at:

http://euweb.aiib.org/html/aboutus/introduction/Membership/?show=0

${ }^{71}$ See: 'Full text: Action plan on the Belt and Road Initiative', issued by the National Development and Reform Commission, Ministry of Foreign Affairs and Ministry of Commerce, with authorization of the State Council, People's Republic of China, 28 March, 2015. Available at:

http://english.gov.cn/archive/publications/2015/03/30/content 281475080249035.htm ${ }^{72}$ Ibid. 
Iran, Turkey, the Balkans, central and eastern Europe, and finally, Germany and the Netherlands. Whereas the 'Maritime Silk Road' will link south-east China with south-east Asia, Bangladesh, India, the Persian Gulf and the Mediterranean, ultimately also ending up in Germany and the Netherlands.73 The AIIB will be tasked with at least partially financing much-needed infrastructure all along and across the land (Silk Belt) and sea (Silk Road) routes of this far-reaching Chinese foreign policy initiative. Indeed, the AIIB, along with the NDB and the Silk Road Fund - a specific Belt and Road Initiativerelated Chinese government fund - will lend nearly US\$200 billion to infrastructure projects over the coming decade. 74

Herein lies the greatest challenge to the collectivist notion underpinning the 'Asian values' argument - how to ensure that China does not dominate the AIIB decision-making structures in much the same way as the USA and Western European countries previously did, and still do, with the World Bank and its sister multilateral development banks (MDBs) around the world. As Rachman observes, the warm welcome to the Chinese-established and dominated AIIB is widely perceived as both a reflection of China's growing financial muscle, as well as a reaction to long-held international perceptions of innate pro-Western bias at the Bretton Woods institutions. 75 With regard to the asymmetries within the decision-making structures of the Western international finance

\footnotetext{
73 Peter Ferdinand, 'Westward ho-the China dream and 'one belt, one road': Chinese foreign policy under Xi Jinping', International Affairs Vol.92, No. 4 (July, 2016) 941-957, at 949-950. ${ }^{74}$ Luft, Foreign Affairs (2016) op. cit., at 70.

75 Rachman (2016) op. cit., at 230.
} 
institutions, Mahbubani and Summers caution that the legitimacy of the system depends on the perception that its rules are developed by and applied fairly and equally to all, rather than that they cater to the narrow interests of a few.' ${ }^{76}$

\section{'Asian Values' and Institutional Design of the AIIB}

At this juncture, some basic facts about the AIIB and key provisions of its founding Articles of Agreement can be introduced as follows: This Agreement was adopted on 29 June, 2015, and entered into force on 25 December, 2015. The treaty depository, China's Ministry of Foreign Affairs, has confirmed that instruments of ratification had been deposited by 17 signatory States, with initial capital subscriptions totaling $50.1 \%$ of the shares allocated. 77 Membership of the AIIB is open to members of the World Bank or the ADB, although the Board of Governors is responsible for decisions on new members. Currently, fifty-six members have signed the Articles of Agreement and there are 30 ratifications among these States. Remaining signatory States that have not yet deposited their instruments of ratification are expected to do so by the end of 2016, and become members thereafter. 78

\footnotetext{
${ }^{76}$ Mahbubani \& Summers, Foreign Affairs (2016) op. cit., at 134.

77 Under Article 59 of the AIIB Articles of Agreement, entry into force required deposit of such instruments by at least 10 Signatory States with at least $50 \%$ of the shares allocated.

${ }^{78}$ See: 'AIIB's Charter Enters into Force On 25 December 2015', news item by the Multilateral Interim Secretariat For Establishing the AIIB, on December 25, 2015. Accessible at: http://www.aiib.org/html/2016/NEWS 0116/83.html
} 
The AIIB will have a Board of Governors, a Board of Directors, a President, one or more Vice-Presidents, and such other officers and staff as may be considered necessary.79 Each member of the AIIB will appoint a Governor to represent it on the Board of Governors. All powers of the AIIB are vested in the Board of Governors. ${ }^{80}$ The Board of Governors meets annually and can delegate any of its powers to the Board of Directors except certain reserved powers. ${ }^{81}$ The Board of Directors will be responsible for the direction of the AIIB's general operations and, for this purpose, will exercise all the powers delegated to them by the Board of Governors. ${ }^{82}$ The Board of Directors will supervise the management and the operation of the Bank on a regular basis and will establish an oversight mechanism for that purpose in line with the principles of transparency, openness, independence and accountability. 83 The mechanism is expected to address such areas as audit, evaluation, fraud and corruption, project complaints and staff grievances.

The stated purposes of the AIIB are to: (i) foster sustainable economic development, create wealth and improve infrastructure connectivity in Asia by investing in infrastructure and other productive sectors; and (ii) promote regional cooperation and partnership in addressing development challenges by working in close collaboration with other multilateral and bilateral

\footnotetext{
79 See Article 21 of the AIIB Articles of Agreement (or AIIB Charter)

${ }^{80}$ Article 22(1) of the AIIB Charter.

${ }^{81}$ Article 23(2), ibid.

${ }^{82}$ Article 26, ibid.

${ }^{8}$ Article 26(iv), ibid.
} 
development institutions. ${ }^{84}$ In line with these aims, the AIIB has broad functions, similar to other MDBs around the world. Under its Articles of Agreement, the AIIB's functions include: (i) promoting public and private investment in the Asia region for development, in particular for infrastructure and other productive sectors; (ii) utilizing the resources at its disposal for financing such development in the region; and (iii) encouraging private investment that contributes to economic development in the Asia region, in particular in infrastructure and other productive sectors, and supplementing private investment when private capital is not available on reasonable terms and conditions. 85 The AIIB is therefore set to become the first MDB that is specifically established and institutionally-designed by its predominantly Asian members to provide financial support for infrastructure development and regional connectivity in Asia.

In addition to the USD $\$ 100$ billion of capital subscribed by members, the AIIB has stated that it will raise funds primarily through the issuance of bonds in financial markets as well as through the inter-bank market transactions and other financial instruments. It may also raise funds through borrowing or other means, in member countries or elsewhere. When doing so, the AIIB will seek to obtain the highest credit rating possible to facilitate borrowing in capital markets. ${ }^{86}$ Recipients of AIIB financing may include member countries or

\footnotetext{
${ }^{84}$ Article 1, ibid.

85 Article 2, ibid.

${ }^{86}$ See: AIIB, 'Key Provisions', available at:

http://euweb.aiib.org/html/pagefaq/Key Provisions/
} 
agencies and entities or enterprises in member territories as well as international or regional agencies or entities concerned with the economic development of the region. As the functions and purpose of the Bank focus on the economic development of the Asia region, the Bank could be authorized to provide financing to recipients located outside the region that contributes to the economic development of the Asia region. ${ }^{87}$

Moreover, the AIIB also plans to work in concert with (rather than in competition against) both the ADB and the World Bank to fulfil its functions, which include: (i) promoting public and private investment in the Asia region for infrastructure development and in other productive sectors; (ii) utilizing the resources at its disposal for financing such development in the region; and (iii) supplementing private investment that contributes to economic development in the Asia region when private capital is not available on reasonable terms and conditions. Positive signs of the former relationship (between the AIIB and the ADB) developing can be discerned from their signing of a Memorandum of Understanding at the ADB's 49th Annual Meeting of the Board of Governors in Frankfurt, Germany, setting the stage for, inter alia, jointly financing projects. ${ }^{88}$ The AIIB and ADB have swiftly followed this initiative with the recent announcement that these two Banks will jointly-finance an initial project for a highway in Pakistan to the tune of US\$100 million each, with the United

\footnotetext{
${ }^{87}$ Ibid.

88 See: Asian Development Bank, 'ADB, AIIB Sign MOU to Strengthen Cooperation for Sustainable Growth' ADB News Release, 2 May 2016. Accessible at: https://www.adb.org/news/adb-aiib-sign-mou-strengthen-cooperation-sustainable-growth
} 
Kingdom government's Department for International Development (DfID) also committing a \$34 million grant for the project. The ADB will act as the lead financier and administer both the AIIB loan and the DfID grant for this project. 89

Evidence of both the Asian emphasis on a collective approach to institutional decision-making, as well as the traditional attributes of Western MDBs, can be discerned at the Bank's launch on 25 December 2015, when the AIIB Articles of Agreement (also known as its Charter) entered into force. The then AIIB President-designate Jin Liqun noted, 'our shareholders have worked tirelessly and collegially over the past year to articulate the foundational principles that will underpin the Bank - transparency, openness, accountability and independence - and to develop a state of the art charter and robust policy and governance framework to guide its operations.'9o

Following this up in his inaugural speech at the formal establishment of the AIIB on 16 January, 2016, 91 the now President Jin again clarified that the process of its establishment had been both participatory and inclusive, and moreover, that its Charter embodies the views, voices, and values of its

\footnotetext{
${ }^{89}$ See: 'ADB Approves First Cofinancing with AIIB for a Pakistan Road Project', ADB News Release, 10 June 2016. Accessible at: https://www.adb.org/news/adb-approvesfirst-cofinancing-aiib-pakistan-road-project

90 Jin Liqun, 'Asian Infrastructure Investment Bank's President-designate Hails the Bank's Launch', available at: http://euweb.aiib.org/html/topic/President-designate/ ${ }^{91}$ Jin Liqun, Speech by AIIB President at 'The Asian Infrastructure Investment Bank Inaugural Ceremony', available at: http://www.aiib.org/html/2016/NEWS 0119/87.html
} 
shareholders. He then pledged that the AIIB would do its best to promote broad-based economic and social development through sustainable infrastructure investment in the Bank's member countries, as well as protect the environment and take care of the people in project areas, stating his commitment to run AIIB as an organization which is 'lean, clean and green'.92 These terms have been elaborated by the AIIB as follows: lean, with a small efficient management team and highly skilled staff; clean, an ethical organization with zero tolerance for corruption; and green, an institution built on respect for the environment.93

These aspirational attributes of the AIIB will be juxtaposed against so-called 'Asian values' approach highlighted by Chesterman and Mahbubani (above), namely, a cultural preference for consensual decision-making, favouring pragmatic solutions over ideological strictures, and gradualism over abrupt change, in relation to this new public international finance institution. Mapping the main elements of the 'Asian values' approach on to the three strictures laid down by AIIB President Jin, namely, that of 1) institutional efficiency; 2) transparent and corruption-free decision-making; as well as 3) social and environmental sustainability considerations, represents both a challenge and an opportunity for purveyors of this Asian-oriented approach to show how AIIB governance is different from the generic Western-based international institutional governance model. The institutionalization of these goals of

\footnotetext{
${ }^{2}$ Ibid.

93 See: 'What is the AIIB?', accessible at:

http://www.aiib.org/html/aboutus/introduction/aiib/
} 
efficiency, transparency, and sustainability, provide the criteria upon which to build an evaluative framework for assessing whether an 'Asian values' approach to AIIB governance can prove to be a better model for global economic governance.

To re-iterate: The key novelties of the AIIB are a non-resident board of directors, more delegation of decision-making to AIIB management, and more flexibility in implementing environmental and social safeguards for projects that AIIB decides to finance. These institutional innovations within AIIB governance first need to be assessed according to the criteria of efficiency, transparency, and sustainability, before being further evaluated as to whether their application is reflective of an 'Asian values' approach to institutional economic governance. In other words, is there a link between an 'Asian values' approach to economic governance and these attributes of efficiency, transparency, and sustainability, that the AIIB purports to reflect? Such connexions between intrinsic values, institutional governance structures and evaluative criteria by which to measure individual institutional decisions are difficult to make. For example, it is not clear that more delegation to AIIB management to ensure streamlined decision-making and thus, 'efficiency', is necessarily reflective of the more consensual approach to decision-making, an 'Asian value' that the AIIB would also presumably espouse.

Within this context, it may be noted that several of these AIIB institutional novelties are in fact reflective of the key recommendations of the 2009 Zedillo 
Commision report on World Bank governance reform.94 This commission had a majority of representatives from the developing world and was led by former Mexican president Zedillo. This Zedillo report had already raised specific criticisms of US and European dominance in the World Bank or International Bank of Reconstruction and Development (IBRD) as it is officially known. Essentially, the two main criticisms that are significant in the present circumstances relate to 1) the US and European dominance in voting shares/rights within the overall governance structure of the World Bank, and 2) the unwieldy nature of the Bank's strategic and decision-making bodies, in terms of their capacity for effectiveness and efficiency in their operations.

First, the Commission identified specific concerns regarding the allocation of voting power of in several arms of the World Bank Group. For example, in the World Bank itself, the share of basic votes in total voting power had eroded significantly since its inception, when the basic votes accounted for 11 per cent of total votes. Despite a decision to increase basic votes from the 2.86 per cent in 2009 to a fixed level of 5.5 per cent of total voting power, this level remains low by historical standards and perhaps more significantly, relative to those in

\footnotetext{
94 Ernesto Zedillo et al, Re-Powering the World Bank for the 21 ${ }^{\text {st }}$ Century: Report of the High Level Commission on Modernization of World Bank Group Governance (October, 2009)

Hereinafter, Zedillo Commission Report (2009) Available at:

http://siteresources.worldbank.org/NEWS/Resources/WBGovernanceCOMMISSIONREPOR T.pdf
} 
other MDBs. 95 The same concern holds true for the International Finance Corporation (IFC) - part of the World Bank Group - where the share of basic votes had eroded to just 1.82 per cent when the Commission published its report. ${ }^{6}$ These downward trends in the basic vote proportions have primarily affected the voice and participation of the World Bank's smallest and poorest member States in a negative way.

On the other hand, both in the World Bank and IFC, the shareholdings and voting power of certain growing economies are not proportionate to their relative size in the global economy. The allocation of voting power and the special majority that is required for amending the World Bank's Articles of Agreement also gave rise to the so-called 'US veto'. Quite apart from its practical implications, the Commission noted that this feature of the establishing instrument for the World Bank contributed to the widespread sense that the institution is dominated by its largest shareholder. 97 By contrast, the AIIB Articles of Agreement provide that the basic votes for all its members will constitute 12 percent of the total number of votes at any time. ${ }^{8}$

\footnotetext{
95 For example, in the Asian Development Bank the share of basic votes is fixed at 20 percent of total voting power. See: Zedillo Commission Report (2009) ibid., at p.xi and para.81, at 25 , fn.39.

${ }^{66}$ Ibid., at p.xi and para.96, at 28.

97 Ibid., at p.xii.

${ }^{98}$ See: Article 28(1)(i) of the AIIB Articles of Agreement (or Charter).
} 
Second, the Zedillo report suggested that the Executive Board of the World Bank, with 25 chairs, is too large to serve as an effective strategy-setting and decision-making body. ${ }^{99}$ Accordingly, the Commission recommended adopting a Board of Directors that is relatively compact and therefore arguably more efficient and effective. The Commission proposed that the World Bank Group's Board should be reduced to 20 chairs from the current 25. Moreover, Board consolidation would be achieved in part by reducing the number of European chairs by no less than four. ${ }^{100}$ By contrast, the Board of Directors of the AIIB has less than half of this number, with just 12 Directors: nine elected by regional members and three elected by non-regional members. ${ }^{101}$

A further manifestation of this leaner but arguably still effective approach to the overall governance and institutional decision-making processes of the AIIB lies in the non-residential status of its Board of Directors. ${ }^{102}$ This is at variance to the World Bank's Board, which is permanently resident in Washington D.C. Although the AIIB Board of Directors is expected to have regular 'physical' meetings, there is provision to have 'virtual' meetings as needed at other times. ${ }^{103}$ Technological advances in video/Skype remote conferencing will therefore allow the AIIB to make significant institutional efficiency cost-savings

\footnotetext{
99 Zedillo Commission report (2009) op. cit., at p.xi.

100 Ibid., at p.xiv.

${ }^{101}$ Article 25(1) of the AIIB Charter.

102 Article 27(1), ibid.

103 Article 27(4), ibid., provides that: 'The Board of Directors shall establish procedures whereby the Board can hold an electronic meeting or vote on a matter without holding a meeting.'
} 
before its work program of financial and technical support for infrastructure development even begins.

Finally, one of Mahbubani's main bugbears against US and European dominance of the World Bank and IMF was the fact that the leadership of these global financial institutions is traditionally switched between European and American nationals, in apparent disregard of transparency and meritocracy as a basis for these appointments. This has recently lead Mahbubani and Summers to prescribe that: 'Picking strong leaders for the major international institutions and keeping those institutions' operations from being undermined or politicized would be a major step forward.'104 Mahbubani and Summers have also highlighted the fact that the leadership and dominance of the United States and Europe in these financial institutions has occasionally been exploited to achieve extra-financial goals. ${ }^{105}$ As Nielson et al note, the culture within the World Bank is dominated by a neo-liberal economic theory-based, technocratic approach to problems, while in its operational policy, 'the Bank is characterized by its Washington-centric approval culture.... ${ }^{106}$

\footnotetext{
104 Mahbubani \& Summers, Foreign Affairs (2016) op. cit., at 133.

105 Ibid., at 134 .

${ }^{106}$ Daniel L. Nielson, Michael J. Tierney \& Catherine E. Weaver, 'Bridging the rationalistconstructivist divide: re-engineering the culture of the World Bank', Journal of International Relations and Development, Vol.9 (2006) 107-139, at 109.
} 
In this regard, the AIIB has sought to differentiate itself from the World Bank by not requiring privatization or deregulation as conditions for funding. ${ }^{107}$ Notably, Article 31(2) of the AIIB Charter specifies that only economic considerations shall be relevant to AIIB decisions. This should allow the AIIB to maintain an apolitical and therefore pragmatic approach to the technical aspects of its work, in line with an 'Asian values' orientation towards what works in practice, rather than the fulfilment of any specific political economic theory.

The institutional governance deficiency in the World Bank and IMF leadership selection process identified above has ostensibly been addressed by the AIIB Presidential appointment process, wherein the AIIB Charter provides that the President shall be elected through an open, transparent and merit-based process, by a Super Majority (i.e., greater than 75\%) vote in the Board of Governors, and that he (or she) should be a national of a regional member. ${ }^{108}$ However, given that China's overall vote share in the AIIB is reported to be higher than 25\%, China effectively has a veto on any proposed AIIB Presidential appointment that it does not approve of. This gives rise to similar concerns as those expressed against US and European preferences in World Bank and IMF leadership appointments. Nor will this concern be alleviated by the envisaged growth of this new MDB from a regionally-focussed organization to one with a global reach. While AIIB Member State representatives recognized that the

\footnotetext{
${ }^{107}$ Koh Gui Qing, 'Exclusive: China's AIIB to offer loans with fewer strings attached - sources', Reuters, Business News, 1 September, 2015. Accessible at: http://www.reuters.com/article/us-aiib-china-loans-idUSKCNoR14UB20150901 ${ }^{108}$ Article 29(1), referring to Article 28(2)(ii) of the AIIB Charter.
} 
Board of Governors might need to exercise some flexibility in the future that would reduce the regional shareholding percentage below $75 \%$, they nevertheless agreed that a minimum of $70 \%$ regional shareholding would be important in preserving the regional character of the Bank. ${ }^{109}$

Moving on from examining the 'Asian values' approach in relation to the institutional framework and decision-making procedures of the AIIB, the final substantive section of this article will proceed to assess this approach with specific regard to the environmental and social risk assessment provisions of this new MDB.

\section{The 'Asian Values' Approach to Environmental and Social} Sustainability Risks within AIIB Projects

To begin with, Article 13(1) of the Charter provides that when making financing decisions, the Bank will be guided by 'sound banking principles in its operations'. The Bank has also undertaken to ensure that each of its operations complies with its environmental and social policies. Specifically, the Bank shall ensure that each of its operations complies with the Bank's operational and financial policies, including without limitation, policies addressing environmental and social impacts. ${ }^{110}$ These policies are in turn subject to approval by the Board of Directors in accordance with Article 26 and will be based on international best practices. ${ }^{111}$

\footnotetext{
109 Article 5(2) \& (3) of AIIB Charter, op. cit.

110 Article 13(4), ibid.

${ }^{111}$ See: Report on the Articles of Agreement of the AIIB, by the Chief Negotiators for
} 
Within this context, one of the main concerns raised by international civil society/non-governmental organizations (NGOs) over the streamlined decision-making systems and procedures for AIIB lending relates to the potentially reduced oversight role that these procedures may provide over social and environmental impacts of the approved infrastructure development projects funded by the new Bank. In recognition of these concerns, the Board of Directors of the AIIB committed to the establishment of environmental and social policies for the Bank, resulting in the adoption of an Environmental and Social Framework in February, 2016.112 This environmental and social policy framework was developed through a consultative process with AIIB's Founding Members and other stakeholders. ${ }^{113}$ In this regard, the overall Framework is composed inter alia of an Environmental and Social Policy (ESP) comprising mandatory environmental and social requirements for each project that the Bank finances, as well as Environmental and Social Standards (ESSs) comprising three associated mandatory sets of environmental and social standards, which in turn establish more detailed environmental and social requirements. ${ }^{114}$

Establishing the AIIB, Singapore, 22 May, 2015. 4pp, at 3. Accessible at: https://www.aiib.org/en/about-aiib/basic-documents/_download/articles-ofagreement/basic_document_report_on the articles_of agreement.pdf ${ }^{112}$ Available at AIIB website:

http://www.aiib.org/html/aboutus/Operational Policies/Environmental Social/?show $=3$ 113 See: AIIB, Environmental and Social Framework, February, 2016. Available at: http://www.aiib.org/uploadfile/2016/0226/20160226043633542.pdf ${ }^{114}$ See: AIIB, Environmental and Social Framework, February, 2016, op. cit. 
However, even prior to the publication of this Framework and its associated Policy and Standards, specific concerns had already been raised regarding both the consultation and implementation of these standards for AIIB-supported projects. ${ }^{115}$ As Kim notes, no one can be certain of the extent of the AIIB commitment to environmental and social sustainability until detailed information on how the new Bank decides which projects it will fund is known. ${ }^{116}$ While information about the precise decision-making criteria, procedures, as well as applicable social and environmental standards within AIIB-funded projects have yet to be published, discernible institutional differences are already emerging and they may lead to different outcomes in practice.

For example, the AIIB aims to have a simpler internal review and risk assessment system for projects compared with its peers in order to hold down costs and cut red tape. This is now manifest in the AIIB Risk Assessment

${ }_{115}$ Navigating the New Normal: China and Global Resource Governance, by Felix Preston, Rob Bailey and Siân Bradley (from Chatham House) \& Dr Wei Jigang and Dr Zhao Changwen of the Development Research Center (DRC) of the Chinese State Council, Joint DRC and Chatham House report, 16 January, 2016, at 31. Available at:

https://www.chathamhouse.org/sites/files/chathamhouse/publications/research/2016-0127-china-global-resource-governance-preston-bailey-bradley-wei-zhao-final.pdf ${ }^{116}$ Jisan Kim, 'Regulating Economic Development: Environmental and Social Standards of the AIIB and the IFC', Harvard Journal of International Law, April 21, 2016. Available at: http://www.harvardilj.org/2016/04/regulating-economic-development-environmental-andsocial-standards-of-the-aiib-and-the-ifc/ 
Framework, ${ }^{117}$ whose risk philosophy aims to be the foundational pillar of the Bank's risk management and the guiding basis for the entire risk governance framework. ${ }^{118}$ The AIIB's high-level, overarching philosophy of its 'risk management' function is constituted by the following three aims in its 'Mission Statement':

i) Enable the Bank to fulfill its mandate to promote infrastructure and other productive sectors;

ii) Ensure the stability and financial continuity of the Bank through efficient capital allocation and utilization, and comprehensively manage risks and reputational consequences;

iii) And foster strong risk culture by embedding risk accountability in the Bank.'119

The AIIB Risk Assessment Framework then elaborates on the last of these aims with the following statement: 'As an integral part of the institution's operations, AIIB takes extra precaution in appropriately managing its risks, and will only aim to take risks which it understands thoroughly and can adequately manage.'120 (emphasis added)

It is notable that there is no explicit mention of environmental and social sustainability risks here, at least until these are defined in paragraph 26 of the

117 AIIB Risk Asessment Framework, published: November, 2016. Available at: https://www.aiib.org/en/policies-strategies/_download/risk-management-framework/AIIB$\underline{\text { Risk-Management-Framework-final-14Nov-clean.pdf }}$

${ }^{118}$ Ibid.., at para.7.

119 Ibid., at para.8.

120 Ibid., at para.8.1.1. 
AIIB Risk Framework by direct cross-reference to its Environmental and Social Framework, as follows: 'Environmental and Social Risk is the risk of breaching any environmental and social rules and commitments as covered in the Bank's Environmental and Social Framework.' Paragraph 36.1 of the Risk Framework then builds on this cross-reference in the following way: 'Integrity, Environmental \& Social, and Reputational Risks management and mitigation comprises the identification of the most relevant risks for the Bank along with their accompanying impact assessment; mitigation and crisis management; reporting and monitoring; as well as developing an action plan. With respect to projects, such risks are managed through the applicable Bank operational policies and directives and their application in the preparation and implementation of projects, including the corresponding policy assurance.'

While it is possible to conclude from these provisions that environmental and social sustainability considerations are now included within the AIIB decisionmaking criteria, and thereby also integrated into the AIIB project decisionmaking process; the fact remains that the AIIB is not expected to unnecessarily delay project approvals to allow all parties to do due diligence. Such delays are a common feature at the World Bank and other MDBs as they have become more risk-averse over time but this has in turn led to criticism that these MDBs have become slow and bureaucratic. Notwithstanding the optimal outcomes these different institutional priorities and practices might stimulate through competition between MDBs for prime international development finance projects, the advent of the AIIB has already prompted other MDBs to review how they work. Such MDB competition to finance major projects can be to the 
potential benefit of prospective borrowers, but also to the possible detriment of social and environmental sustainability in relation to these projects.

Moreover, the simplification of due diligence, particularly when combined with the less-risk averse loan/investment decision-making procedures that the AIIB has already trailed as one of its operational efficiency aims, does not augur well for the last of the three strictures that the AIIB has bound itself to uphold, namely, international best practice in the application of social and environmental standards. This issue is especially pertinent when we consider that one of the stated aims of the AIIB is to focus on major infrastructure development projects. Such major projects almost inevitably result in equally significant social and environmental impacts, thereby necessitating more, not less, due diligence on the part of institutional lenders such as the AIIB.

Initial assessments of the AIIB environmental and social framework have yielded a mixed bag of results. A World Resources Institute comment observed that: 'On some issues, the AIIB has embraced more progressive positions than some of its peers. For example, the AIIB excludes financing for commercial logging operations in tropical or old-growth forests, which goes beyond the current commitment made by the World Bank. On other subjects, the AIIB's commitments are not quite as strong. For example, the AIIB has not followed the lead of the ADB or International Finance Corporation (IFC) in giving Indigenous Peoples the right to consent to activities taking place on their lands. ${ }^{121}$

${ }^{121}$ Gaia Larsen and Sean Gilbert, 'Asian Infrastructure Investment Bank Releases New 
According to Kim, many environmental provisions of the AIIB Standards are on par with that of the IFC Performance Standards on Environmental and Social Sustainability. ${ }^{122}$ For instance, in its pollution prevention section, the AIIB cites the World Bank Group's Environmental, Health and Safety Guidelines (EHSGs) and ensures that its projects will follow these EHSGs. On the other hand, the AIIB Standards lack detail or are different in ways that may lead to arbitrary outcomes. Kim has outlined a few examples of these discrepancies, as follows:

1) The IFC Performance Standards provide more detailed requirements on how adverse environmental effects should be mitigated, applying specific terms such as 'no net loss' of biodiversity and 'set-aside' areas of significant biodiversity value. ${ }^{123}$ By contrast, the corresponding AIIB requirement appears to be merely to 'avoid adverse Project impacts on biodiversity. When avoidance of adverse impacts is not possible,

Environmental and Social Standards: How Do They Stack Up?', World Resources Institute Blog Post, 4 March, 2016. Available at:

http://www.wri.org/blog/2016/03/asian-infrastructure-investment-bank-releases-newenvironmental-and-social-standards

122 The latest version of the IFC Performance Standards was adopted on 1 January, 2012. Available from IFC website, at:

http://www.ifc.org/wps/wcm/connect/c8f524004a73daecaogafdfg98895a12/IFC Performa nce Standards.pdf?MOD=AJPERES

${ }^{123}$ See, for example, paragraph 15 under IFC Performance Standard 6 on Biodiversity Conservation and Sustainable Management of Living Natural Resources. 
implement measures to minimize adverse impacts and restore biodiversity, including, as a last resort, biodiversity offsets. ${ }^{124}$ The AIIB requirements are therefore not as detailed as the IFC's, inter alia providing that any conversion or degradation of natural habitats is appropriately mitigated through 'measures acceptable to the Bank'. ${ }^{125}$ According to Kim, if the AIIB is not rigorous in its evaluation of mitigation measures, recipients of funding may be able to escape with implementing measures that are superficial, cheap, and ineffective; 126

2) For projects located in natural habitats, the AIIB requires a cost-benefit analysis of the proposed project to be undertaken, to ensure that, inter alia, the Project's overall benefits substantially outweigh the environmental costs. ${ }^{127}$ As the IFC Standards do not have a similar requirement, the IFC may finance projects even if the overall economic benefits are deemed not to 'substantially outweigh' the environmental costs. Nevertheless, Kim cautions that such cost-benefit analysis will not always lead to wise decisions, because it is unclear how the AIIB will conduct cost-benefit analyses, so the ultimate decision could be arbitrary. Indeed, the AIIB may allow projects that significantly destroy natural habitats by simply concluding that the overall benefit of the

\footnotetext{
124 See: 'B. Environmental Coverage', in AIIB Environmental and Social Standard 1: Environmental and Social Assessment and Management.

125 Ibid.

${ }^{126}$ See: Kim, Harv $J$ of Int L (2016) op. cit.

${ }^{127}$ AIIB Environmental and Social Standard 1, op. cit.
} 
Project does in fact 'substantially outweigh' the cost. Thus, the costbenefit analysis might be used to justify or defend AIIB's decisions to value economic gain over environmental protection; ${ }^{128}$

3) Finally, when critical habitats of high biodiversity value are involved, the IFC will not implement any project activities unless several imperative criteria are met. These criteria include the fact that there will be no measurable adverse impacts on this biodiversity and the ecological processes supporting this biodiversity, as well as no net reduction in global, regional or national populations of endangered species in these critical habitats. By contrast, while there appears to be a similar, initial presumption that AIIB-sponsored 'Project activities in areas of critical habitats are prohibited', the AIIB then focuses on whether any adverse impacts impair the habitat's 'ability to function'. ${ }^{129}$ Based on the different wording and emphasis in these separate texts, Kim postulates that the AIIB may ultimately allow a project by determining that a habitat may be able to function even if many of its biodiversity values are lost, whereas the IFC would not allow a project that would reduce biodiversity values, even if the habitat were able to function. ${ }^{130}$

\section{AIIB and World Bank Group Co-ordination Initiatives}

While concerns remain over the current lack of adequate social and

\footnotetext{
${ }^{128} \mathrm{Kim}$ (2016) op. cit.

${ }^{129}$ AIIB Environmental and Social Standard 1, op. cit.

${ }^{130} \operatorname{Kim}$ (2016) op. cit.
} 
environmental impact considerations, as well as the simplified decision-making procedures within the AIIB, there are signs that both the AIIB and its Western counterparts have recognised the need for co-operation and coordination of their efforts, if only to prevent wastefulness and 'race to the bottom' scenarios in relation to the social and environmental impacts of infrastructure projects they finance. Thus, a recent World Bank press release announced the signing by World Bank Group President Jim Yong Kim and AIIB President Jin Liqun of the first Co-Financing Framework Agreement between the World Bank and AIIB in April, 2016.131 The Agreement outlines the co-financing parameters for World Bank/AIIB investment projects and paves the way for the two institutions to jointly develop projects.

Pursuant to this Agreement, the World Bank and the AIIB are currently discussing nearly a dozen co-financed projects in sectors that include transport, water and energy in Central Asia, South Asia and East Asia. In 2016 alone, the AIIB expects to approve about $\$ 1.2$ billion in financing, with World Bank joint projects anticipated to account for a sizeable share of this overall total. Significantly, in relation to the previously expressed concerns over social and environmental considerations, it is the World Bank that will prepare and supervise the co-financed projects under this institutional co-financing agreement in accordance with its policies and procedures in areas like

\footnotetext{
${ }^{131}$ World Bank and AIIB Sign First Co-Financing Framework Agreement, April 13, 2016. Available at: http://www.worldbank.org/en/news/press-release/2016/04/13/world-bankand-aiib-sign-first-co-financing-framework-agreement
} 
procurement, environment and social safeguards. ${ }^{132}$

\section{Conclusions}

As we look forward to the third decade of the $21^{\text {st }}$ Century, the advent of the Asian Infrastructure Investment Bank has afforded us a welcome opportunity to re-visit the 'Asian values' debate to see whether these values still have traction as a means to both explain and assess the institutional design of this new Multilateral Development Bank, as well as advance a new variety of capitalism, while maintaining social cohesion and environmental resilience. As a stark projection of Chinese, and wider Asian, economic power, the AIIB represents a real statement of intent on the growing role that Asian governments can and should play on the global economic governance stage. Interrogating both the perception and reality of Chinese dominance of the AIIB also represents a microcosm of how China is 'defending, contesting and negotiating with the liberal global order in a historically contingent social world with a view to shaping normative change in global international society.' 133 Whether the growing influence of Chinese (and wider Asian) power within these new forms of international governance across the world will also bring about a change of institutional culture, to one that is imbued by 'Asian values', is a compelling international policy and legal research question for the near future.

This essay has hopefully provided a situational context in which we can trace both the positive and negative attributes of such 'Asian values' within the AIIB

\footnotetext{
${ }_{132}$ Ibid.

${ }_{133}$ Zhang, International Affairs (2016) op. cit., at 797.
} 
and possibly other new MDBs as well, with a view to assessing whether these values have been successfully promoted and implemented within these new forms of global economic governance. Time will tell whether an increasingly 'Asian values'-influenced set of international economic and finance institutions, beginning with the AIIB examined here, can better lead the world to a more socio-economically and environmentally sustainable future. To this end, the present essay should serve as a basic building block of a new research agenda for assessing whether the future operations of this Bank, as well as other new MDBs, uphold an 'Asian values' approach to global economic governance. 